\title{
Neutralizing Binding Antidrug Antibody Measurement
}

National Cancer Institute

\section{Source}

National Cancer Institute. Neutralizing Binding Antidrug Antibody Measurement. NCI

Thesaurus. Code C147273.

The determination of the neutralizing binding antidrug antibody in a biological sample. 